\title{
Striped Blister Beetle, Epicauta vittata (Fabricius) (Coleoptera: Meloidae) ${ }^{1}$
}

John L. Capinera ${ }^{2}$

\section{Introduction and Distribution}

The striped blister beetle, Epicauta vittata (Fabricius), is a native species. It has been collected from all eastern states west to, and including, South Dakota, Nebraska, Kansas and Oklahoma. In Canada it is known from Quebec and Ontario. Populations from the southeastern coastal plain including Florida, southern Georgia and eastern South Carolina differ in appearance from beetles found elsewhere and are called the 'lemniscate race,' but interbreed successfully with normal beetles.

\section{Description and Life Cycle}

There are one to two generations per year. In Arkansas, the May-June or early-emerging adults go on to produce another generation in which adults emerge in September. Maximum emergence of adults occurs in July, however, and few of the later-emerging adults contribute to the second generation. The generations overlap, resulting in adults present in the field from late May to late October. Overwintering occurs as instars 5 and 6. In Florida, the season is considerably advanced, with most adults found during April through June.
Egg: The eggs of striped blister beetle are whitish in color and average about $1.8 \mathrm{~mm}$ in length and 0.7 $\mathrm{mm}$ in width, though the length ranges from 1.4-2.1 $\mathrm{mm}$. They are elongate oval, with rounded ends. The eggs are deposited in the soil within a tubular chamber at a depth of 3 to $4 \mathrm{~cm}$, normally in clusters of 100 to 200 eggs. The female covers the eggs after oviposition, and hatching occurs in 10 to 16 days. Eggs can be found from June through September in Arkansas. Females are reported to produce several hundred eggs in captivity, though this estimate may be low because many closely related species produce 2000 to 3000 eggs during the life span of 20 to 50 days.

Larva: As is typical with blister beetles, the larva initially has long legs and is quite mobile. The legs become reduced in size, however, as the larva develops, and instars 6 and 7 (if present) have small head capsules and do not feed. Newly hatched larvae are whitish in color but soon turn reddish brown with dark brown bands on the thorax and abdomen. The first instar must disperse from the egg mass and locate grasshopper eggs on which to feed. Once locating a grasshopper egg pod, the larva feeds and

1. This document is EENY-280, one of a series of Featured Creatures from the Entomology and Nematology Department, Florida Cooperative Extension Service, Institute of Food and Agricultural Sciences, University of Florida. Published: January 2003. This document is also available on Featured Creatures Website at http://creatures.ifas.ufl.edu. Please visit the EDIS Website at http://edis.ifas.ufl.edu.

2. John L. Capinera, professor/chairman, Entomology and Nematology Department, Institute of Food and Agricultural Sciences, University of Florida, Gainesville, FL 32611.

The Institute of Food and Agricultural Sciences (IFAS) is an Equal Employment Opportunity - Affirmative Action Employer authorized to provide research, educational information and other services only to individuals and institutions that function without regard to race, creed, color, religion, age, disability, sex, sexual orientation, marital status, national origin, political opinions or affiliations. For information on obtaining other extension publications, contact your county Cooperative Extension Service office. Florida Cooperative Extension Service / Institute of Food and Agricultural Sciences / University of Florida / Larry R. Arrington, Interim Dean 
molts at short intervals. The mean duration of the first five instars, all of which feed on grasshopper eggs, is $3.4,1.2,1.1,1.6$, and 11.3 days, respectively, at warm temperatures. Overwintering also may occur in the fifth instar, followed by pupation in the spring. Alternatively, larvae may display a sixth and seventh instar before pupation, with the sixth instar persisting for about 230 days and the seventh for six to 14 days. Seventh instars are found from April through July at about the same time other individuals are pupating or emerging as adults. Mean larval head capsule widths (range) are 0.63 (0.53-0.82), 0.83 (0.75-0.91), 1.10 (0.93-1.20), 1.64 (1.37-1.75), 2.28 (2.18-2.37), 1.73 (1.37-2.18), and $2.42(1.75-2.68) \mathrm{mm}$ for instars 1 to 7 , respectively.

Pupa: The pupal stage is found in the soil. The pupa greatly resembles the adult in form, though the wings and legs are tightly drawn to the ventral surface. Initially the pupa is whitish in color but becomes darker with maturity. Duration of the pupal stage is nine to 13 days. Pupae are found in May-August.

Adult: The adults measure 9 to $17 \mathrm{~mm}$ in length and are black and yellow in color. The color pattern varies geographically, but normally two black spots occur dorsally on the head, two black stripes occur dorsally on the thorax, and the elytra each bear two or three black stripes. Northern populations often bear only two black stripes on the elytra whereas southern populations usually bear three black stripes. The southern coastal plain race, which has three stripes on each elytron, is termed the lemniscate race. Like most other blister beetles, the adult is elongate and slender in form, the thorax is narrower than the head and abdomen, and the legs and antennae are moderately long. The body bears numerous small punctures, and is densely clothed with short hairs. The elytra are long, covering the abdomen but separated or divergent at the tips. The hind wings are transparent.

The adults are most active during the morning and late afternoon, seeking shelter from the sun at mid-day. In particularly hot, arid climates they remain inactive during the day, confining activity to the evening hours. They are easily disturbed, dropping readily from the plant and hiding or scurrying away if disturbed. The preovipositional interval of striped blister beetle is about 20 days, with a 10 day interval between production of egg masses.

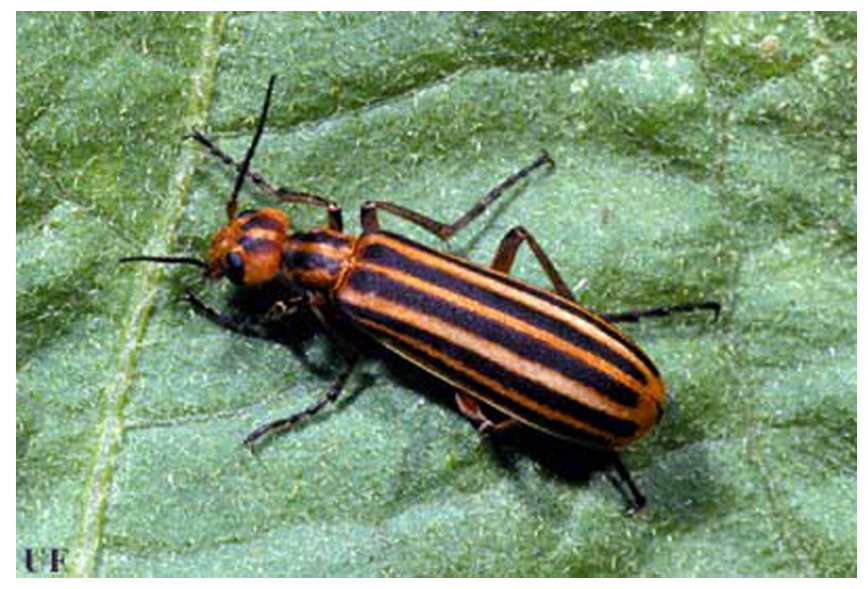

Figure 1. The striped blister beetle, Epicauta vittata (Fabricius), showing the three black stripes on the elytra found on southern US populations. Credits: University of Florida

The adults of striped blister beetle are very similar to Epicauta occidentalis Werner and E. temexa Selander and Adams, and these species frequently have been confused in the literature. Also, "Epicauta lemniscata" has been used for reference to these species, and to mixed populations of these species. Adams and Selander (1979) provide a detailed description of striped blister beetle, and keys to separate this species from close relatives. Biology of striped blister beetle is included in the publications of Gilbertson and Horsfall (1940) and Horsfall (1943). Werner (1945) and Pinto (1991) includes this species in keys to North American Epicauta. Downie and Arnett (1996) provide keys to the eastern species of blister beetles, though these are derived from Werner's.

\section{Host Plants}

Vegetable crops such as bean, beet, carrot, cabbage, Chinese cabbage, corn, eggplant, melon, mustard, pea, pepper, potato, radish, spinach, squash, sweet potato, tomato, and turnip are sometimes injured. Clover and soybean can also be attacked. Pigweed, Amaranthus spp., is highly preferred by adults. 


\section{Damage}

Striped blister beetle is one of the most damaging of the blister beetles to vegetable crops in areas where it occurs. This is due to its feeding preferences, which include several common crops and greater preference for foliage than some other species; its propensity to feed on fruits of solanaceous plants; its relatively large size and voracious appetite; its strong tendency to aggregate into large mating and feeding swarms; and its high degree of dispersiveness, which can result in sudden appearance of large swarms of beetles. It also has been implicated in the transmission of bean pod mottle virus to soybean.

Preference of black blister beetle and other blister beetle species for alfalfa can result in harm to horses Aggregations of beetles can be incorporated into alfalfa hay when it is baled, particularly if the stems are crushed as part of the harvesting process. Crushing, or crimping, aids in the drying and preservation of hay, but also can result in death of aggregations of blister beetles, and incorporation of their bodies into the hay. Blister beetles, even dead individuals, contain a vesicating substance called cantharidin which, when ingested, damages the digestive tract of animals. Cantharidin also causes blisters to form on the skin of sensitive humans who come into contact with crushed beetles, and in formation of blisters in the mouths of livestock, particularly horses. This blistering action is the basis for the common name of the beetles. Cantharidin content varies among species, ranging from 5\% cantharadin in Epicauta immaculata to about $1 \%$ cantharidin in E. pensylvanica (Capinera et al.1985). Despite the relatively low toxin content in each beetle, large numbers can be incorporated into hay, and horses can ingest enough beetles to cause death (Blodgett et al. 1991). Cantharidin likely serves as a feeding deterrent to most predators, thereby protecting blister beetles and their eggs from consumption. .

The damage caused by Epicauta spp. blister beetles is offset, at least during periods of relatively low beetle density, by the predatory behavior of blister beetle larvae. Epicauta spp. larvae feed on the eggs of grasshoppers, including many crop-damaging
Melanoplus spp. During periods of grasshopper abundance the number of blister beetles tends to increase substantially. Studies of egg pod destruction in western states during a period of grasshopper abundance, for example, documented that $8.8 \%$ of pods were damaged by blister beetles. Although the blister beetles eventually contribute materially to the suppression of grasshopper population outbreaks, the higher numbers of blister beetles often cause greater crop injury during, and immediately after, periods of grasshopper abundance. The larvae of blister beetles other than Epicauta spp., however, seem to feed principally on ground nesting bees (Hymenoptera: Andrenidae, Halictidae, perhaps others) and the bee's nest provisions. Their abundance fluctuates less, and they provide no known agricultural benefits.

\section{Natural Enemies}

Little is known concerning the natural enemies of striped blister beetle, though they are taken by robber flies (Diptera: Asilidae) and avian predators, including meadowlark, Sturnella neglecta Audubon; bluebird, Sialia sialis (Linnaeus); and scissor-tailed flycatcher, Muscivora forficata (Gmelin). There also are reports of predation of striped blister beetle eggs by the predatory blister beetle Epicauta atrata (Fabricius).

\section{Management}

Blister beetle populations are easily controlled by foliar application of insecticides. The tendency of beetles to aggregate, however, may result in serious defoliation in small areas of a field, and little or no damage elsewhere. Thus, careful visual examination of plants is suggested, followed by spot treatment of infested areas.

For more management information see:

Insect Management Guide for Vegetables (http://edis.ifas.ufl.edu/TOPIC_GUIDE_IG_ Vegetables)

Insect Management Guide for Field Crops and Pastures (http://edis.ifas.ufl.edu/TOPIC_GUIDE_ IG_Field_Crops_and_Pastures). 
Striped blister beetle is reportedly closely associated with grasshoppers that produce large egg pods, particularly twostriped grasshopper, Melanoplus bivittatus (Say) and differential grasshopper, $M$. differentialis Thomas. Neither of these grasshopper species occurs in Florida, which may account for the infrequent problems with striped blister beetle in this state. Striped blister beetle adult feeds readily on alfalfa, and can be abundant in this crop even in the absence of grasshoppers. This host preference may contribute to the scarcity of striped blister beetle in Florida, as alfalfa is rarely grown in such warm climates.

\section{Selected References}

Adams CL, Selander RB. 1979. The biology of blister beetles of the Vittata group of the genus Epicauta (Coleoptera, Meloidae). Bulletin of the American Museum of Natural History 162. 266 pp.

Anonymous. Blister beetle. North Carolina Pest Management Information. http://ipm.ncsu.edu/AG271/soybeans/ blister_beetle.html (24 December 2002).

Bailey WC, Enns WE, Loch W. (October 1993). Blister beetle management in alfalfa. http://muextension.missouri.edu/xplor/agguides/ crops/g04569.htm (24 December 2002).

Blodgett SL, Carrel JE, Higgins RA. 1991. Cantharidin content of blister beetles (Coleoptera: Meloidae) collected from Kansas alfalfa and implications for inducing cantharidiasis. Environmental Entomology 20: 776-780.

Capinera JL, Gardner DR, Sternitz FR. 1885. Cantharidin levels in blister beetles (Coleoptera: Meloidae) associated with alfalfa in Colorado. Journal of Economic Entomology 78: 1052-1055.

Downie NM, Arnett Jr. RH. 1996. The Beetles of Northeastern North America. Vol I and II. Sandhill Crane Press, Gainesville, Forida. 1721 pp.

Gilbertson GI, Horsfall WR. 1940. Blister beetles and their control. South Dakota Agricultural Experiment Station Bulletin 340. 23 pp.
Horsfall JL. 1943. Biology and control of common blister beetles in Arkansas. Arkansas Agricultural Experiment Station Bulletin 436. 55 pp.

Pinto JD. 1991. The taxonomy of North American Epicauta (Coleoptera: Meloidae), with revision of the nominate subgenus and a survey of courtship behavior. University of California Publication Entomology Bulletin 110. 372 pp.

Werner FG. 1945. A revision of the genus Epicauta in America north of Mexico (Coleoptera, Meloidae). Bulletin of the Museum of Comparative Zoology 95: 421-517. 